\title{
Networked National Private TV Mass Disobedience Against Obligations of 10\% Local Broadcasts in
}

\author{
Willyanto ${ }^{1}$, Rachma Ida ${ }^{2}$, Novri Susan ${ }^{3}$, Meithiana Indrasari ${ }^{4}$, Rosnindar Prio Eko Rahardjo \\ ${ }^{1,2,3,5}$ Faculty of Social and Political Sciences, Airlangga University Surabaya, Indonesia \\ ${ }^{4}$ Faculty of Economics, University of Dr. Soetomo Surabaya, Indonesia
}

\{1ahmad.willyanto@mncgroup.com\}

\begin{abstract}
Democratization of broadcasting in Indonesia was built starting with the enactment of Broadcasting Law No. 32 of 2002 concerning networked broadcasting systems. With the network broadcasting system there is no television station that is centered in Jakarta, television stations must have network stations in each of the desired areas. This system includes the obligation to broadcast locally by $10 \%$ of the number of broadcasts per day. One of the empirical phenomena is the non-compliance of the majority of the national networked private television in the area against one of the contents of the broadcasting law. This article looks at in detail how the national networked private television station understands local broadcasts in the area. By using qualitative research methods that also use critical discourse analysis as an analysis, the results to be obtained are to provide a detailed analysis of the reluctance of the networked national private television stations to the obligations of $10 \%$ of local broadcasts. A detailed description of the political economy theory of the media on the decision of the networked national private television station in interpreting local broadcasts is a fundamental reason for the decision.
\end{abstract}

Keywords: Network Broadcasting System, obligation of 10\% Local Broadcasting, Critical Discourse Analysis, Media Political Economic Theory.

\section{INTRODUCTION}

The principal democratic role of the media, according to the liberal theory, is to act as a check on the state. The media should monitor the full range of state activities, and fearless expose abuse of official authority. (Curran, 2000). What was said by James Curran, a professor of communication from Goldsmith Collage, the University of London above in his book "Mass Media and Society" would not have materialized in Indonesia if there had not been a reformation in 1998. The reform ultimately brought fundamental changes in all fields, both in the economic, political and socio-cultural fields of society. No exception in the field of mass media, especially in the field of television broadcast media, namely the democratization of the broadcasting system in Indonesia.

Post-reform euphoria contributed to the birth of new policies in the realm of broadcasting in Indonesia summarized in the Broadcasting Law no. 32 of 2002. One of the main policies in 
it is the arrangement of networked broadcast systems. Private television broadcast system which aims to even distribution of broadcast content and television station ownership.

Network concept According to Head and Sterling (1982), defines it as: "Two or more stations interconnected by some means of relay (wire, cable, terrestrial microwaves, satellite) so as to enable simultaneous broadcasting of the same program... ". Two or more stations are interconnected through relays (wires, cables, terrestrial microwaves, satellites) that allow the program to be broadcast simultaneously. Article 34 paragraph 1 and 2, PP No. 50 of 2005 concerning the Implementation of Private Broadcasting Institutions, states that the networked television system in Indonesia (Network Station System / SSJ) is a television system that requires televisions that have national broadcast frequency power, to release frequency on their broadcast areas and submit to people / institutions / regional organizations who want to use it to be developed. If televisions located in Jakarta want their broadcasts to be accepted in certain areas, then they must cooperate with television in the area concerned. This system was implemented in Indonesia on December 28, 2009. National TV can act as the parent of the network station and the local TV acts as a member of the network station, the main station acts as the coordinator whose broadcast is bridged by members.

According to Chesney, there needs to be an equal distribution of media ownership, because if there is a concentration of media in sole ownership, then it will endanger the democratic process. (Chesney, 2000), so that regional TV stations as network station members can get the opportunity to maximize regional potential in the form of production and broadcasting local broadcast programs, as stipulated in the broadcasting law, namely by giving $10 \%$ of the total broadcast time for one day, or 2.5 hours per day if the network television host broadcasts 24 hours a day.

Answering this, the government issued the Broadcasting Law no. 32 of 2002 . The broadcasting law contains in it regional rights to be able to use the regional frequency spectrum, also regulates how institutional mechanisms outside the region in utilizing regional frequency. This is what became known as the network broadcasting system (SSJ).

Law no. 32 of 2002 concerning networked broadcast systems in Indonesia, primarily aimed at making television broadcasting not centralized which led to the democratization of broadcasts. Networked broadcast system raises diversity of content and diversity of ownership. Rianto (2012) said that broadcasting service providers are public broadcasting institutions, private broadcasting institutions, community broadcasting institutions, and networked broadcasters. With the presence of various types of broadcasting, various 'voices' are expected to emerge so that the diversity of content and ownershipwill always be maintained.

\section{REVIEW OF THEORY}

\subsection{Local Broadcast}

Regional broadcast material is part of the diversity of content referred to in the broadcasting law. The network broadcast system guarantees local content through broadcasting local programs as much as $10 \%$ of broadcast time throughout the day as a form of democratization of broadcasting in Indonesia. P3SPS (Broadcasting and Standards Program Conduct Guidelines) as the "operational guidelines" of the Broadcasting Law, also defines what is meant by local programs are programs produced by regional human resources and carried out in the regions and have local content.

The broadcasting of local content as much as $10 \%$ for networked national television in the regions as mandated by the Broadcasting Law, is carried out by each television station with 
different meanings. Even though it has equally allocated 2.5 hours a day, there are differences in the program's production process. The majority of networked national television in the regions produce most of their local programs in Jakarta, with the remainder being carried out in the regions. The majority also has local content in local programs that are being worked on. Among those doing such practices are RCTI, Trans TV, MNC TV, AN TV, Indosiar, and GTV.

For local governments, the $10 \%$ model of local content fulfillment as practiced by networked national private television in the regions has not been said to be in line with what the Broadcasting Law no. 32 of 2002. One reason is that networked national television stations in producing local programs are not carried out in the regions, and do not use regional resources.

\subsection{Political-Economic Media}

In line with the study of media political economy which was coined by Vincent Mosco (2009):

Commodification is defined as the process of transforming goods and services, including communication, wich are valued for their use, into commodities wich are valued for what they will bring in the marketplace. There are three types of commodification that are important to communication: the commodification of content, of audiences, and of labour.

That national networked private television prioritizes the production of local programs in Jakarta, because it is carried out by personnel who have better skills than those in the region. The results of the regional program work in Jakarta have similar qualities with the national program, so there is no difference in quality between local programs and national programs. Economically, if local slots are sold to the national market, it will be far more profitable than if sold to the local market. On iNews TV, TVC packages sold in the local market are subject to a rate of 250 thousand per spot (30 seconds) and if sold nationally the rate can reach 1.5 million per spot (30 seconds). So if converted between the production costs of local programs in the area and profits from the sale of local ad slots in the area, the production costs will be far greater. That is, the acquisition of advertising in the area is not sufficient to finance the operation of network stations in the area.

Even though the consideration of political economy is prioritized by national private television in running networked broadcasting systems in the regions, and referring to the critical discourse analysis faircloughnourman methodology (Haryatmoko, 2016) they must maintain the mandate of the Broadcasting Law as well as possible. The existence of regional communities through mass media must also be prioritized in order to maintain the democratization of broadcasting in the country. If not, then what is a concern for James Curran will be the weakening of public supervision through the media on the course of the wheels of government in power at the beginning of writing, which will really happen.

\section{METHODS}

To carry out this study, the authors used The Case Study Method. In general, case studies are a more suitable method if the research questions used in the formulation of the problem are how that requires clarification (Yin 2008: 1-10). So this case study research method was deliberately chosen because it was considered the most relevant or suitable to answer the question 'how' in a phenomenon.

The target of this study was a Surabaya local newspaper with East Java distribution area. Duta Masyarakat is a Public Daily with a research focus on communication strategies 
marketing the newspaper in maintaining its life so that it can become a newspaper industry that grows and develops business in the era of information and communication technology such as with the focus of marketing communication strategies in order to maintain life and develop media business in the digital era.

The unit of analysis that will be observed involves several informants, including: Mokhammad Kaiyis (President Director), Imam Ghozali, (Advertizing Manager), Mokhammad Khakim (Editor in Chief), Putut Kartika Candra (Financial Manager), Syamsul Huda (Marketing Manager)

The method of data collection in this study was carried out by in-depth interview and observation techniques. Data in this study is divided into two parts, namely primary data and secondary data. Primary data is obtained through in-depth interviews with informants and observations. Secondary data is all forms of written documentation or evidence that is relevant and can be used to support research.

The analysis techniques use theconstant comparative method, as stated by Glaser \& Strauss in the book they are the Dsicovery of Grounded Research) with the aim of obtaining the right results after comparing one data with other data both from informants and from data in the form of documents and archives.

Triangulation is used as a combination or combination of various methods used to examine phenomena that are interrelated from different perspectives and perspectives. Denzin (1978) in Moleong (2016: 330) mentions triangulation techniques include four things, namely method triangulation, inter-researcher triangulation (if research is conducted with groups), data source triangulation, and theory triangulation.

\section{RESULTS AND DISCUSSION}

Until the end of July 2016, there was still a warm conversation about EDP (Hearing Evaluation) extension of the Broadcasting License of 10 private television broadcasting (national) and becoming the parent network with the domicile of business entities in Jakarta. Some people questioned the role of KPI to really evaluate the 10 television track record for 10 years broadcasting "nationally" from 2006 to 2016. Many people perceive the TV station's list of "sin" as a strong reason for KPI not to recommend the feasibility of broadcasting content of several TV stations including the government to no longer extend its Broadcasting License for the next 10 years until 2026. It is related to the requirements of diversity of content minimum of $10 \%$.

Diversity of content requirements are now emerging in the middle of the implementation of the Network Station System (SSJ). The reason is that private broadcasting institutions (LPS) or commonly called national private TV stations are required to comply with the minimum requirements of diversity of content of $10 \%$.

LPS began to question the realization of the portion of local content. If the SSJ is designed to provide a variety of broadcasts for the local community, national TV has already done it. To fulfill the $10 \%$ requirement is indeed not easy. Television stations have to pack local broadcasts as attractive as possible so as not to lose and still be able to attract advertisements. Moreover, the potential for broadcasts in each region varies. Regarding content, national TV is indeed worthy of worry. The problem is, in addition to relying on advertising as the main income, they have to prepare the procurement of transponders.

The Indonesian Broadcasting Commission made a warning to at least 10 national TV and local TV stations that had switched to network TV that did not show 10 percent of local content. But after 3 months have not shown an increase in the presence of local content in their broadcasts, the KPI calls to all broadcasters and finally reaches an agreement. After 
passing through 2015 yesterday, KPI has conducted a further evaluation of the agreement and the increase is quite significant. On average the broadcasters have fulfilled broadcasts with local content as much as 90 minutes in accordance with the agreement.

In the near future, KPI invite the National TV again to deliver and remind them of commitments that must be adhered to. Apart from that, in fact as much as 30 percent of the 10 percent provision for the display of local content must be aired at prime time. Because so far a number of National TVs that have fulfilled the provisions of local content only display local content on ghost clocks that are less effective and are not widely watched by the public.

\section{CONCLUSSIONS}

The Indonesian Broadcasting Commission made a warning to at least 10 national TV and local TV stations that had switched to network TV that did not show 10 percent of local content. But after 3 months have not shown an increase in the presence of local content in their broadcasts, the KPI calls to all broadcasters and finally reaches an agreement. After passing through 2015 yesterday, KPI has conducted a further evaluation of the agreement and the increase is quite significant. On average the broadcasters have fulfilled broadcasts with local content as much as 90 minutes in accordance with the agreement.

In the near future, KPI invite the National TV again to deliver and remind them of commitments that must be adhered to. Apart from that, in fact as much as 30 percent of the 10 percent provision for the display of local content must be aired at prime time. Because so far a number of National TVs that have fulfilled the provisions of local content only display local content on ghost clocks that are less effective and are not widely watched by the public.

Fulfillment of the $10 \%$ requirement for broadcasting local content that is still simple and unsold to advertisers to cover production costs. However, after the EDP 10 the networked television station signed a letter of commitment to repair conditions to meet the requirements for a nationwide networked broadcast system.

\section{Refferences}

Caporaso, James \& David P. Levine. (2008). Teori-teori Ekonomi Politik. Yogyakarta, Pustaka Pelajar.

Curran, 2000. “Mass Media and Society”. Arnold London, Co-published in the United States of America by Oxford University Press Inc., New York.

Haryatmoko, 2016.”Critical Discourse Analysis (Analisis Wacana Kritis) Landasan Teori, Metodologi dan Penerapan. Jakarta.

McChesney. (2000). "Rich Media, Poor Democracy: Communication Politics in Dubious Times." Monthly Review Press. New York. AS

Morissan. (2008) "Manajemen Media Penyiaran, strategi mengelola Radio \& Televisi". Prenadamedia group, Yogyakarta.

Rianto, Puji. (2012) dkk. "Dominasi TV Swasta (Nasional) Tergerusnya Keberagaman Isi dan Kepemilikan". PR2Media, Yogyakarta.

Vincent Mosco. 2009.:" The Political Economy Of Communication." Sage Publication. London.

Undang-undang Penyiaran dan Pers (2011). Bandung : Fokus Media. 